\title{
Linking Management and Riparian Physical Functions to Water Quality and Aquatic Habitat
}

\author{
Donald F. Kozlowski' ${ }^{1}$, Robert K. Hall ${ }^{2}$, Sherman R. Swanson ${ }^{3}$, Daniel T. Heggem ${ }^{*}$ \\ ${ }^{1}$ USDA Forest Service, Beckwourth Ranger District, Plumas National Forest, Blairsden, CA, USA \\ ${ }^{2}$ USEPA Region IX, WTR2, San Francisco, CA, USA \\ ${ }^{3}$ Natural Resources \& Environmental Sciences, University of Nevada, Reno, NV, USA \\ ${ }^{4}$ USEPA Office of Research \& Development, NERL, Environmental Sciences Division, Las Vegas, NV, USA \\ Email: "heggem.daniel@epa.gov
}

Received 13 January 2016; accepted 27 June 2016; published 30 June 2016

Copyright (C) 2016 by authors and Scientific Research Publishing Inc.

This work is licensed under the Creative Commons Attribution International License (CC BY).

http://creativecommons.org/licenses/by/4.0/

(c) (7) Open Access

\section{Abstract}

Stream and wetland riparian areas are able to sustain a state of resiliency based on the ecosystem's ability to attain the functions of its ecological potential. This resiliency allows an area to provide and produce desired and valued water quality and aquatic habitat ecosystem services. Maintaining healthy aquatic and riparian habitats depends on "management" allowing for, or facilitating natural recovery of riparian functions. Altering grazing management practices in Maggie Creek lead to changes in riparian functionality, water quality, and aquatic habitat. Maggie Creek basin, historically renowned for its fishery, is one of only a few watersheds in Nevada capable of supporting Lahontan Cutthroat Trout (LCT) (Oncorhynchus clarkia ssp. Henshawi) meta-populations. Prior to 1993, the majority of Maggie Creek was grazed by cattle throughout the growing season. Decades of intensive grazing, water development, and road construction degraded aquatic and riparian habitats. By the early 1990's, a majority of the Maggie Creek watershed was rated as nonfunctional or functional-at-risk condition with unstable banks, channel incision, loss of riparian vegetation, wide shallow channels, excessive erosion and deposition, reduced stream flows, and increased water temperatures. As mitigation for their 1993 South Operations Area Project mine dewatering, Newmont Mining Company, in cooperation with the Elko District Bureau of Land Management (BLM) and the Elko Land and Livestock Company, developed the Maggie Creek Watershed Restoration Project to enhance LCT habitat. The project was developed to enhance 82 miles of stream, 2000 acres of riparian habitat and 40,000 acres of upland watershed primarily through prescriptive livestock management. Beginning in 1994, grazing systems were implemented for portions of the perennial/intermittent streams. This greatly reduced the frequency

\footnotetext{
${ }^{*}$ Corresponding author.
}

How to cite this paper: Kozlowski, D.F., Hall, R.K., Swanson, S.R. and Heggem, D.T. (2016) Linking Management and Riparian Physical Functions to Water Quality and Aquatic Habitat. Journal of Water Resource and Protection, 8, 797-815. 
and duration of hot season grazing on Maggie Creek and its tributaries. The objective of this paper is to compare 1994 and 2006 stream and wetland riparian assessments using proper functioning condition (PFC) protocol and water quality data.

\title{
Keywords
}

\author{
Ecosystem Function, Water Quality, Non-Point Source, Proper Functioning Condition
}

\section{Introduction}

Maintaining healthy aquatic and riparian habitat after natural or anthropogenic disturbance depends on management allowing or facilitating natural recovery of riparian functions. Streams differ in their potential to produce habitats, biota, and water quality for beneficial uses (i.e., swimmable, fishable, drinkable, etc.). Water quality and biological communities vary depending on the stream's ability to attain the functions of its ecological potential. Within the paradigm of water quality standards (WQS), the objective for reducing pollutant loads is to reduce the allowable concentrations. The question is how to reduce loads when many streams are themselves the source of sediment, or nutrients, due to their failure to function properly. In these cases, reducing an external load is not the solution. Rather, riparian functions must be restored to reduce the pollution-releasing processes (i.e., erosion), and engage sequestration and/or assimilation processes. Restoring riparian functions will result in slowing the nutrient spiral with flooding and floodplain deposition and allow nutrient uptake, aquifer recharge, and reconstruction of quality habitat, and complex niches/food webs that integrate riparian and aquatic ecosystems [1].

The current system of water quality regulation is fraught with complications making the TMDL process for NPS poorly focused. Basically, the regulatory system is ineffectual for reducing pollution levels, improving water quality, and restoring habitats [2]. This study documents change in riparian and rangeland management effecting physically functional riparian conditions of streams and tests hypotheses related to changes in water quality. The source of pollution addressed by this study is the stream and riparian area due to its nonfunctional or functional at risk physical condition. The BLM reported that in Nevada only $30 \%$ of riparian miles and $26 \%$ of wetland acres were functioning properly [3]. This dysfunction clearly limits the ability of the TMDL process, to make progress toward meaningful water quality improvement in these areas, especially where the waterway is the pollution source and where riparian functions could remediate pollution and impaired habitats.

Anthropogenically altered water cycles often lead to hydrologic alterations (e.g., increased/decreased volume and velocity of runoff and sediment, size and frequency of floods, altered groundwater recharge and discharge). These alterations frequently create additional environmental stressors via erosional/depositional processes such as channel incision, changes in sediment and chemical concentrations. These changes modify habitats and affect other beneficial uses of water or water bodies. To address the aquatic impacts from environmental stressors, it is important to understand the interconnections of an ecosystem, and also recognize the fundamental changes to riparian ecosystem services coming from changes in hydrology, vegetation, and soil erosion/deposition within a geomorphic context.

Impaired functions accelerate erosion in a long-term chain reaction of geomorphic adjustment leading to significant changes in water quality and aquatic habitats. Sediment is a major pollutant across the nation [4]. Reducing erosion, or inducing sedimentation, has direct water quality implications. Sediment is the primary medium for transporting organic and inorganic chemicals impacting aquatic biota and beneficial uses (e.g., recreation and wildlife). Pathogens and nutrients are the most common biological and chemical stressors to wildland streams and lentic wetlands. Temperature and other environmental variables fluctuate through time and space in relation to diurnal and annual cycles. Properly functioning streams vary the magnitude of the fluctuations within a narrower range. Thus, temperature dependent biological and chemical processes operate with lower variation. Well vegetated and functioning stream and wetland systems typically decrease aquatic insolation and reduce heat exchange through radiation. They ameliorate fluctuations of water volume (down- 
stream low flows and floods) through underground storage with aquifer recharge and hyporheic zone interchange. Thus, winter low temperatures remain higher and summer high temperatures remain lower.

Riparian Proper Functioning Condition (PFC) assessment [5] [6] connects land management to water quality through ecosystem attributes. These attributes lead managers to grasp the story of individual reaches and the overall watershed. Integrated riparian management focuses attention to at-risk reaches and impaired functions so managers can select strategies for remediation and adjust these through time based on monitoring [6]. This study assesses changes in riparian physical functionality and biophysical alterations due to changes in land management strategies. Understanding the drivers of ecosystem function and the resulting changes in water quality and aquatic habitat at a local scale empowers resource managers for adaptive management alternatives.

\subsection{Proper Functioning Condition Development}

PFC is an interagency assessment protocol focusing on physical structure and functioning in relation to on-site potential. Although qualitative, it is based upon quantitative science [5]-[7]. PFC incorporates the important attributes numerically based surveys commonly address [8]. An interdisciplinary team conducting PFC assessment in the field uses all relevant science and life experience to inform understanding of local potential to determine what is locally possible, and what is needed for the system to maintain functions in large flow events. A PFC rating relates how well the physical stream/riparian processes are functioning. To be properly functioning, a riparian system will: "Dissipate stream energy associated with high water flows, thereby reducing erosion and improving water quality; filter sediment, capture bedload, and aid floodplain development; improve floodwater retention and groundwater recharge; develop root masses that stabilize stream banks against cutting action; develop diverse ponding and channel characteristics to provide the habitat and the water depth, duration, and temperature necessary for fish production, waterfowl breeding, and other uses, and; support greater biodiversity" [5].

Riparian Proper Functioning Condition assessment connects to water quality and aquatic habitat by assessing the degree of functionality and the risk of losing this functionality. To determine how well a riparian area functions to achieve these criteria, an interdisciplinary team of experienced professionals uses a checklist of seventeen attributes in three categories: hydrology, vegetation, and erosion/deposition. The functional attributes in the PFC checklist provide important foci for this study's research. The rationale for the PFC assessment, including all seventeen attributes, has been summarized in technical references [9] (revised and elaborated by) [5] [6].

When the stream and riparian system functions properly, it is stable and resilient to major hydrologic events, even those with recurrence intervals of 20 - 25 years [5]. Stream stability requires that a stream be self-sustaining, retain the same general geometry over time (decades), and balance the import and export of sediment [10] [11] describe a Great Basin morphologic setting influenced by climate changes that implies some riparian systems in this region may be more sensitive to disturbance and incision than "typical" streams. The hydrologic/stability interval expressed by [5] suggests possible instability at lower probability/higher magnitude events. Yet PFC streams may buffer the hydrologic and geomorphic stresses of even dam-break events analogous to extremely rare precipitation events. [9] and [5] also describe mechanisms of natural recovery toward a renewed stability with restored functionality borrowing from [12] and many others.

If a riparian area does not function properly, it may not retain the same general geometry over time and may be out of balance regarding sediment transport. If the riparian zone is functioning but stressed or "at risk" because one or more attributes makes it susceptible to degradation, it may be prone to excess channel changes during major disturbances such as flooding or fire. These alter water levels and plant growing conditions, degrade nutrient uptake, and accelerate erosion. Undissipated hydraulic energy detaches particles ineffectively bound by roots. [13] modeled changes in several stream channel attributes of burned northern Nevada riparian zones using PFC attributes, functional ratings, precipitation, and upland and riparian burn severity.

\subsection{Maggie Creek}

The Maggie Creek Watershed is in northeastern Nevada within the northern Great Basin (a temperate desert with cold snowy winters and hot dry summers) and drains to the Humboldt River basin (Figure 1). Maggie 
Creek Watershed is bounded by the Tuscarora Mountains on the west and the Independence Mountains to the north and east.

The National Hydrologic Dataset (NHD) indicates the Maggie Creek Watershed has 1094 stream miles, predominantly intermittent or ephemeral, with 224 miles of perennial reaches in 11 sub-basins (Cherry Spring, James Creek, Cottonwood Creek, Simon Creek, Jack Creek, Coyote Creek, Fish Creek, Beaver Creek, Chicken Creek, Lone Mountain Creek and Coon Creek) (Figure 2). Elevation ranges from about 1435 to $2700 \mathrm{~m}$. The Tuscarora Mountains supply most of the runoff for Maggie Creek. Most precipitation is deposited as snow, especially at higher elevations. Snowmelt and spring flow are the major sources of water. The thirty year average (1970-2000) precipitation of the watersheds in the general area range from $284-830 \mathrm{~mm}(11.2-32.7$ inches). Maggie Creek is comprised of 11 sub-basins.

Most of the watershed is in the Upper Humboldt Plains level IV ecoregion [14] except for the Semiarid Uplands of the Tuscarora Mountains on the basin's west side. Land cover is primarily shrub/scrub of short and mountain big sagebrush (Artemisiatridentata Nutt. ssp. Vaseyana) with Idaho fescue (Festucaidahoensis Elmer) and other grasses. Some juniper and aspen forests occupy headwater areas of tributaries. Riparian vegetation consists primarily of willow communities. Smaller meadow areas of hay/pasture are located mostly along waterways. The primary land uses include ranching, hay production requiring diversions of stream water, and mining. As described, Maggie Creek is a microcosm representative of the northern Great Basin.

Maggie Creek Watershed covers 254,150 acres, of which BLM administers 42\% and manages eight small and three large grazing allotments (Figure 2), 55\% is privately owned and 3\% is owned by the state of Nevada (Figure 2(a)).

Maggie Creek Watershed covers 254,150 acres, of which BLM administers 42\% and manages eight small and three large grazing allotments (Figure 2), 55\% is privately owned and 3\% is owned by the state of Nevada (Figure 2(a)).

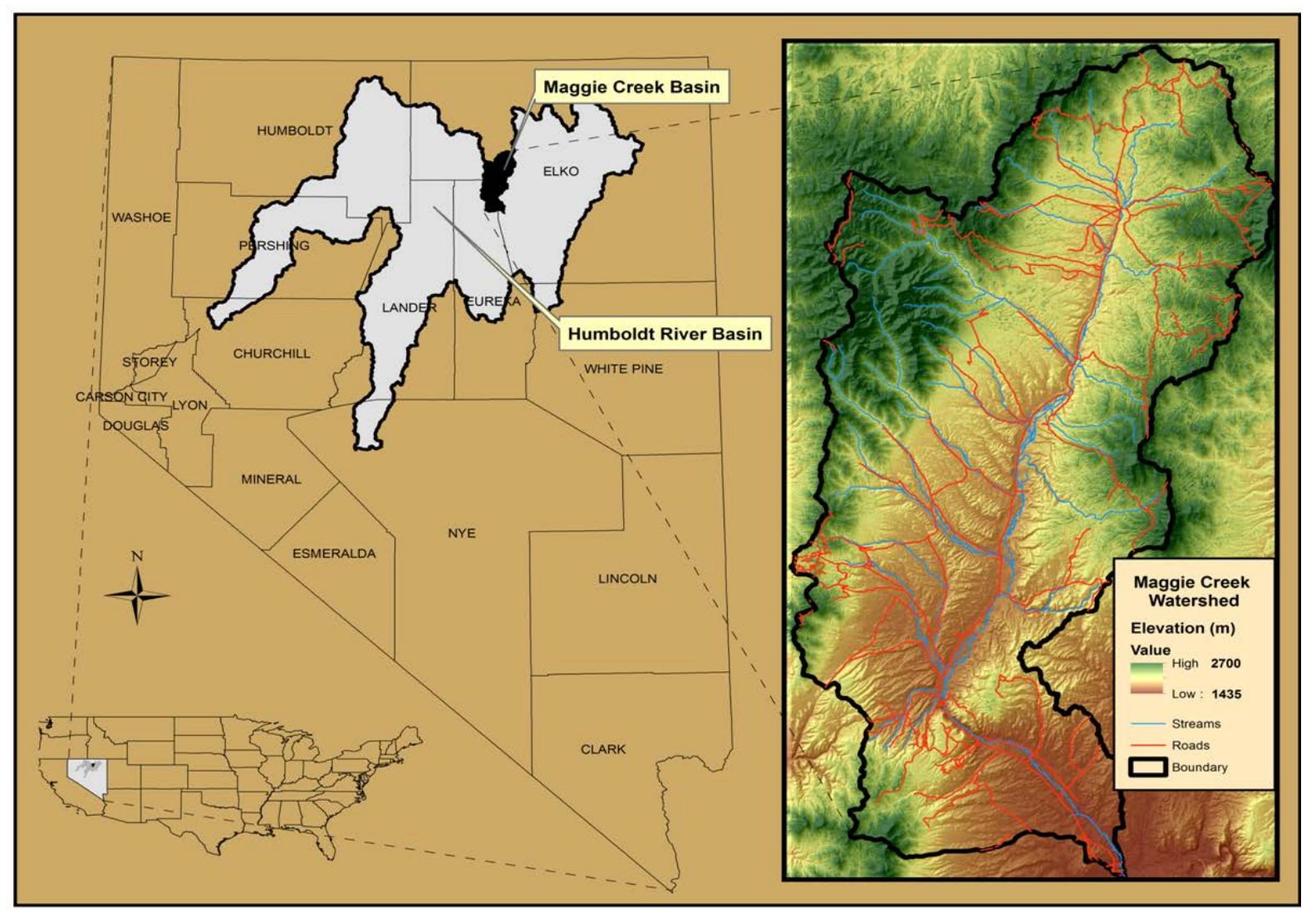

Figure 1. Location of map of the Maggie Creek watershed northeastern Nevada within the Humboldt River basin. 
(a)

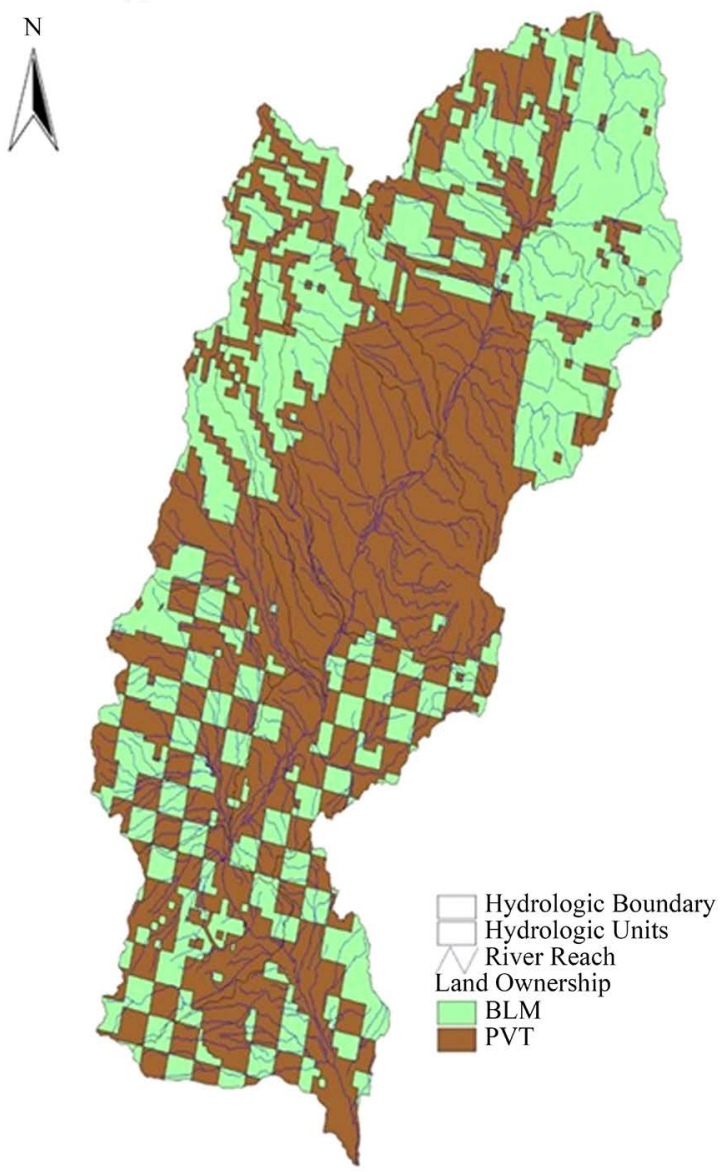

(b)

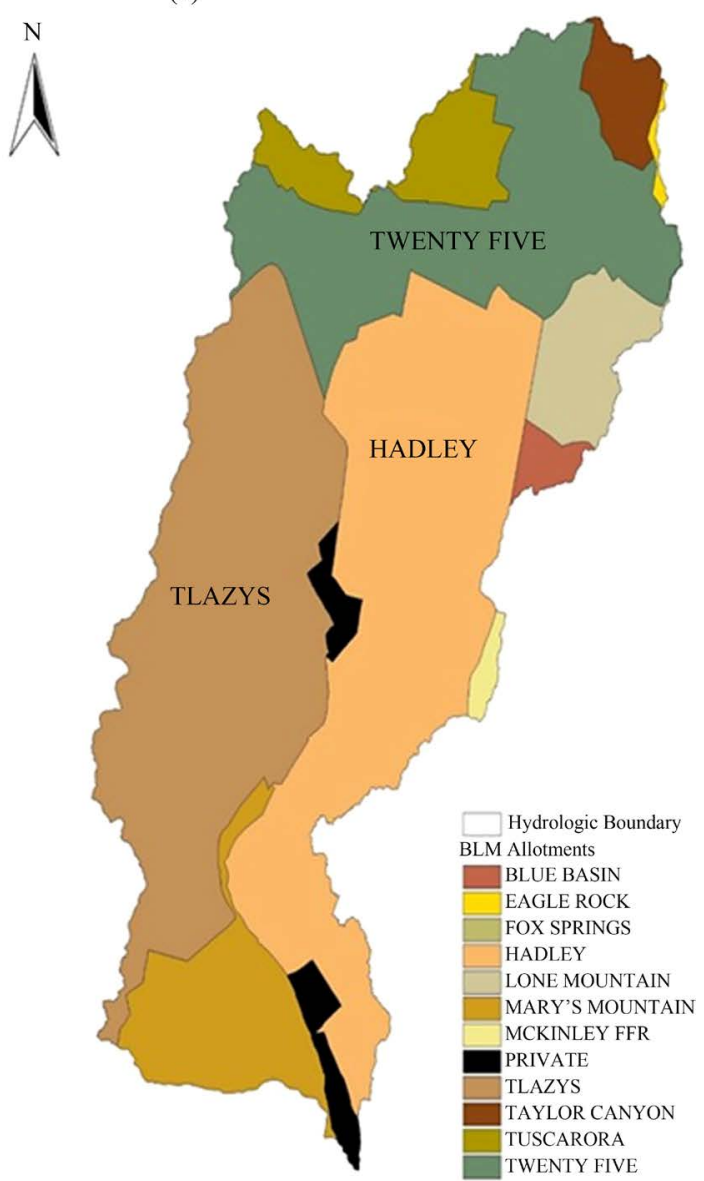

Figure 2. Location of map of the Maggie Creek watershed northeastern Nevada within the Humboldt River basin.

Historical records indicate commercial ranching began in the Maggie Creek watershed in the late 1870's around the time the T Lazy S Ranch was amassing vast acreages via homesteading and railroad land acquisitions (Figure 2(a)). Land use then consisted of open range grazing and developing irrigated hay production, particularly in the Rock Creek and Humboldt drainages. The T Lazy S Ranch has since been renamed the TS Ranch, which today has private holdings and grazing allotments within the Maggie Creek Watershed (Figure 2(b)). The Hadley and Twenty-Five ranches also operate within the watershed. The TS Ranch is managed by the Elko Land \& Livestock Company, a subsidiary of current owner Newmont Mining Corporation (Newmont), which purchased the ranch in 1986 to gain mineral rights, water rights, and transportation access.

The Carlin Trend, a 50-mile long, 5-mile wide belt of faulted terrain runs northwest to southeast from the town of Carlin, Nevada, through the Maggie Creek Watershed. The Carlin Trend has been called the most prolific goldfield in the Western Hemisphere. Newmont started open pit production on the Carlin Mine (within the lower portion of Maggie Creek Watershed) in 1965. With the discovery of higher grade gold at depth, underground mining began in 1994, necessitating mine water extraction and mitigation [15].

During the period of this study, the 2001 Coyote Fire burned 11,637 acres primarily in the Beaver Creek sub-basin (Figure 3). In the same year, the Maggie Creek Fire burned approximately 2550 acres in the southeast portion of the watershed. The Basco Fire, in 2006, burned approximately 11,750 acres in northeast of the watershed (Figure 3). Collectively, 9.8\% of the watershed burned during this study. This area is normal or below normal, given the historic fire return intervals for similar vegetation types [16] [17].

\section{Methods}

Stream differences are often discussed or classified using stream order [18], valley confinement and landform 


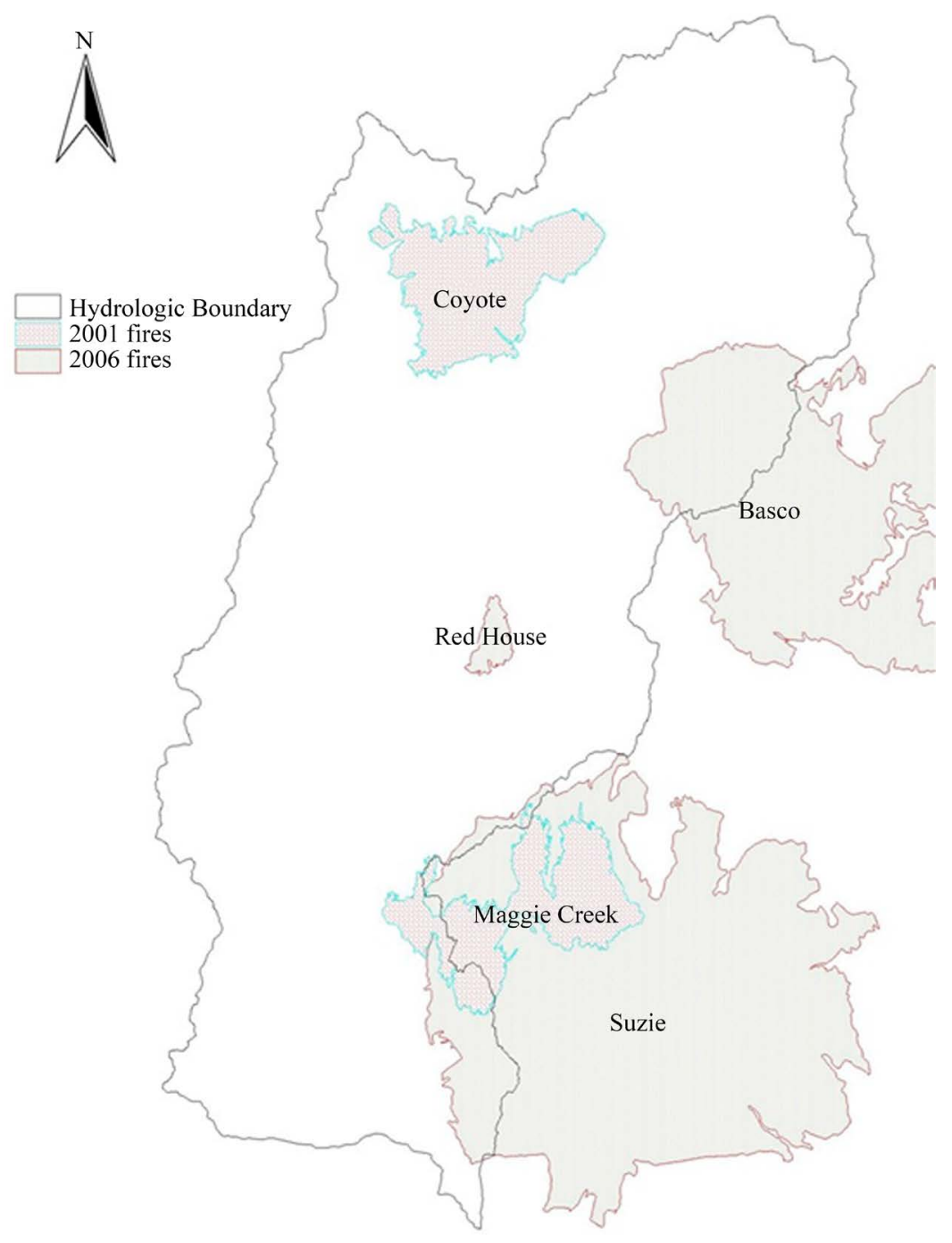

Figure 3. Maggie Creek, NV, fire event areas.

setting, gradient, substrate, entrenchment, width/depth ratio, sinuosity, and bed form [19]-[21]. Differences are caused by climate and geologic parent material, as well as historic and prehistoric human modifications [22] [23]. Riparian vegetation exerts strong influences on channel form and ecological processes [5]. The importance of riparian vegetation and its differing roles in various geomorphic and ecological settings has led to numerous riparian vegetation classifications [24] and scorecards [8] [25].

Stream riparian functional condition was assessed using the methods of [5] and [26]. Evaluations were performed for the years 1994 and 2006 because of the availability of imagery by an interdisciplinary team composed of a hydrologist, geomorphologist, and ecologist. The year 1994 is important because it preceded management changes, and 2006 reflects recent conditions within the period of water quality data. Much of this assessment was done through remote sensing data in ArcGIS. 2006 Color Infrared (CIR) and National Agriculture Imagery Program (NAIP) 1-meter resolution imagery were used (with other ancillary data) to assess PFC assessment for 2006. 1994 black-and-white (B\&W) Digital Orthophoto Quarter-Quadrangles (DOQQs) and CIR 1-meter imagery (with other ancillary data) were used to assess PFC for 1994. 1994 CIR imagery (obtained from the BLM) is not complete for the entire Maggie Creek Watershed. It covers the major tributaries of Simon Creek, Jack Creek, Coyote Creek, and Spring Creek as well as Maggie Creek proper upstream nearly to Beaver Creek. Beaver Creek and the main channel and tributaries to the north were evaluated with B\&W only. While some interpretations about vegetation status can be made using B\&W photography, use of these images limits what interpretations can be made in the vegetation category of PFC assessments. For both years, some on-the-ground 
photography was available from stream surveys performed by the BLM. Very Large Scale Aerial (VLSA) imagery was flown by Open Range Consulting in 2006 (provided by the BLM) for some portions of Maggie Creek, Coyote Creek, and Beaver Creek. Where available, all these images were used to help assess PFC condition.

Determining riparian plant vigor (attribute 10) from the aerial photos was difficult. The influence of vigor on long-term water quality is also assessed by other PFC variables. Stream stability within assessed reaches is not dependent upon coarse and/or large woody debris (attribute 12). Where sticks provide a similar role along small brushy streams, that role is well addressed by attribute 6 and especially attributes 11 and 13. Therefore, PFC attributes 10 and 12 are not addressed further.

Stream reaches to be assessed were defined as a homogenous management unit (i.e., fence line to fence line). Reaches were to be perennial stream systems. The upper reaches of the stream were not assessed if perennial streams were disconnected by an ephemeral reach. Approximately 53 perennial stream miles were assessed as 98 reaches (Figure 4(a)). The assessed area was the low gradient portion of Maggie Creek. The upper reaches were not assessed because middle reaches were ephemeral. Beaver Creek Riparian Pasture restoration and controlled grazing zones are outside of the accessed reaches. The perennial upstream reaches valued for fish and riparian habitat were isolated from downstream reaches and were not expected to influence water quality at sampling stations except during unusually high flow conditions. Downstream exclosure, restoration, and controlled grazing pastures comprised 14 of the 53 miles assumed to most directly affect water quality.

Water quality data for this study was provided by Newmont Mining Co., Nevada Division of Environmental Protection (NDEP), and US Geological Survey (USGS). Study area is divided into 2 analysis areas, Upper and Lower. MAG2 (upper station) water quality data were associated with flow data from USGS gauging station 1,031,950, which represents a location further up in the watershed (Figure 4(b)). Lower stations are represented by sampling locations HUM82, HS14, 1,032,200, and the one lowest in the watershed MAG1 (Figure 4(b)),
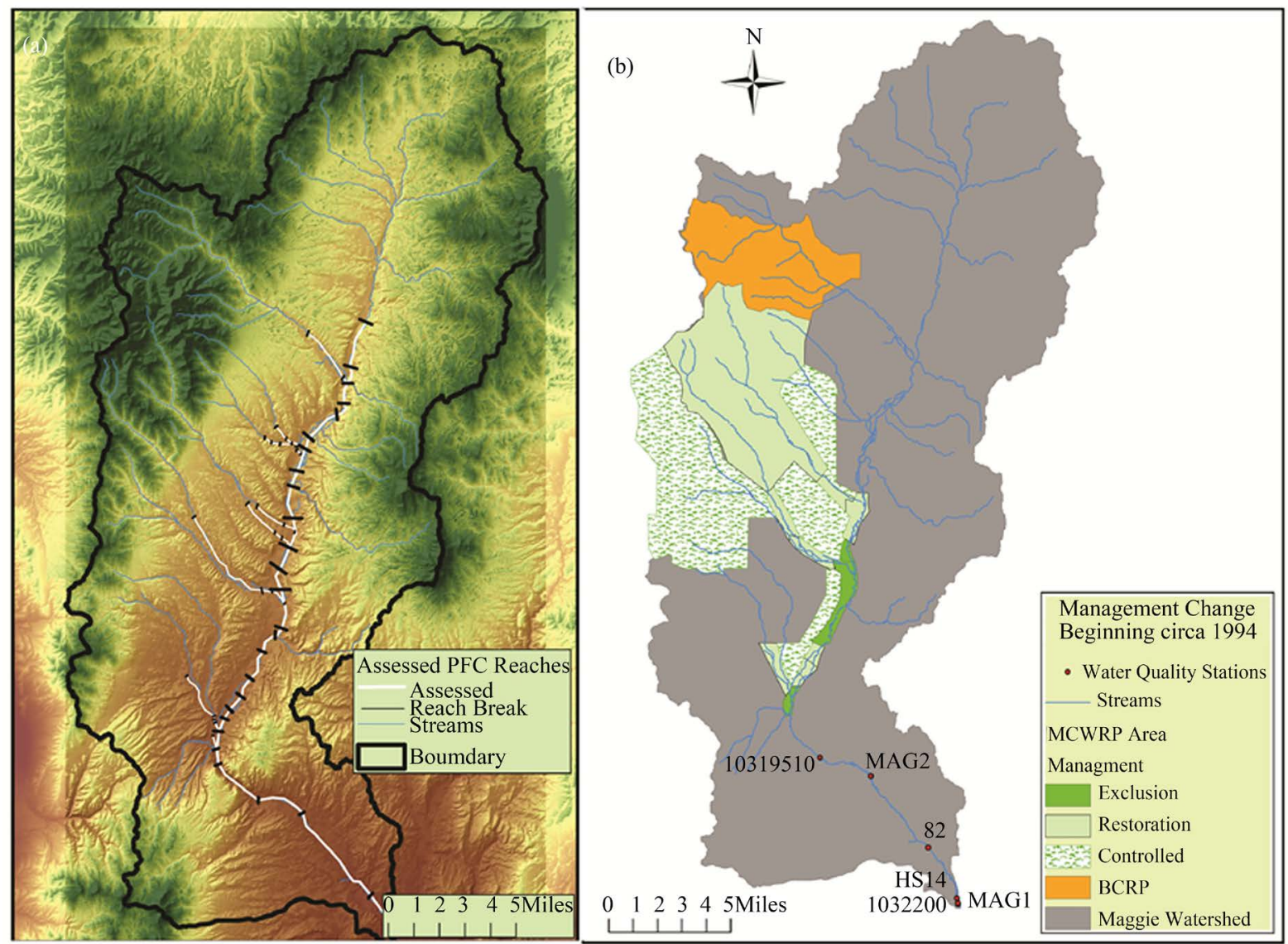

Figure 4. (a) PFC stream reaches assessed along Maggie Creek, NV. (b) Management change and water quality stations in the maggie creek watershed restoration project (MCWRP) and the beaver creek riparian pasture (BCRP), NV. 
which is most closely associated with flow data from USGS gauging station 1,032,200.

Data for precipitation was obtained from the National Oceanic and Atmospheric Administration (NOAA) National Climatic Data Center (NCDC) (http://www.ncdc.noaa.gov/oa/ncdc.html) for the Elko airport, the closest available data source that spans the time of the study. Yearly precipitation data indicate six years had below average precipitation while eight where above average. Four of the six below average years are clustered together in the middle of the study period from 1999 through 2002.

Available stream flow data for the period of study (1994-2006) were obtained from the USGS National Water Information System (NWIS, http://waterdata.usgs.gov/nwis) for the stations 1,031,950 and 1,032,200 within the Maggie Creek Basin. Station 1,032,200 does not have data for 1990-1992. The 1993 data from the two stations were used to create a predictive regression model to fill in relatively dry 1990-1992 data gaps. USGS Station $10,322,000$ is on Maggie Creek near the confluence to the Humboldt River. USGS station 10,321,950 is located approximately nine miles upstream. Newmont Mining Co. developed a reservoir on the east side of Maggie Creek basin and about 7 miles upstream with the confluence of the Humboldt River. The reservoir was built before the beginning of this study and after changes in land management. The reservoir is designed to hold water from mine dewatering activities and supply cool water to Maggie Creek. Discharge at USGS station 1,032,200 is influenced by additional flow from the reservoir. Flows prior to the middle of 1994 were generally lower than the above station 10,321,950. After 1994, flows were higher, marking the beginning of the reservoir's influence. Yearly peak discharges are similar at the two stations. Above average precipitation is recorded at Elko from 2003 through 2006. This is evidenced by higher spring discharges during the same time period. There does not appear to be a return of continuous base flows at station 10,321,950 as there was prior to July of 2000. At station $10,321,950,90 \%$ of all flows are below approximately $55 \mathrm{cfs}$ (bankfull discharge) and $70 \%$ are below $10 \mathrm{cfs}$. No flow is recorded about $27 \%$ of the time. The average flow at this station is about $24 \mathrm{cfs}$, the median is $4.5 \mathrm{cfs}$, and the mode is $0 \mathrm{cfs}$.

\section{Results}

\subsection{Proper Functioning Condition Assessments}

As seen in Table 1 the percent change of assessed stream miles for PFC attributes and PFC rating on Maggie Creek and its tributaries are shown. Note attributes 2, 4, 6, 7, 9, 11, 13, 14, and the functional rating all had more than $10 \%$ change on either Maggie or the total miles assessed. While arbitrary, it was decided $10 \%$ or greater represented a robust enough change for attribute or rating's role to be further evaluated as a driver of water quality change. While individual tributaries had greater percentages of change, the relative length of stream miles to the whole was small (collectively only $3 \%$ ).

Although open pit mining is prevalent in this watershed, PFC assessments using aerial images revealed no evidence that tailings or sediment from upland erosion or natural mass wasting would contribute to stream degradation of any studied reach (attribute 5, Table 1). One example of mass wasting high on the Coyote Creek tributary occurred above miles of ephemeral channel and was therefore disregarded as per reach rules. Thus sediment pollution or riparian degradation issues are likely to originate from erosional processes within the stream channel itself.

The functional rating of Maggie Creek improved on $13 \%$ of the stream miles assessed and constitutes the largest portion of the $13.2 \%$ increase in functionality of the system overall. The largest contributors to this increase include an increase in active/stable beaver dams, an increase in the diverse age classes, composition, and amount of adequate well-rooted riparian plant communities, and an improvement of floodplain/channel energy dissipation characteristics.

\subsection{Total Suspended Solids}

Total suspended solids (TSS) data collected at the upper station ranged from 0 (non-detectable or ND) to 1100 $\mathrm{mg} / \mathrm{L}$. The average value was approximately $51 \mathrm{mg} / \mathrm{L}$, the median was $12 \mathrm{mg} / \mathrm{L}$, and the mode was $10 \mathrm{mg} / \mathrm{L}$.

Prior to management change, the trend in TSS at the upper station (Figure 5) was highly influenced by the March, 1993 runoff event. After the change in grazing management in 1994, TSS was influenced by a few smaller events, but Figure 5, demonstrates the need for a sediment rating curve to help interpret high TSS anomalies. 


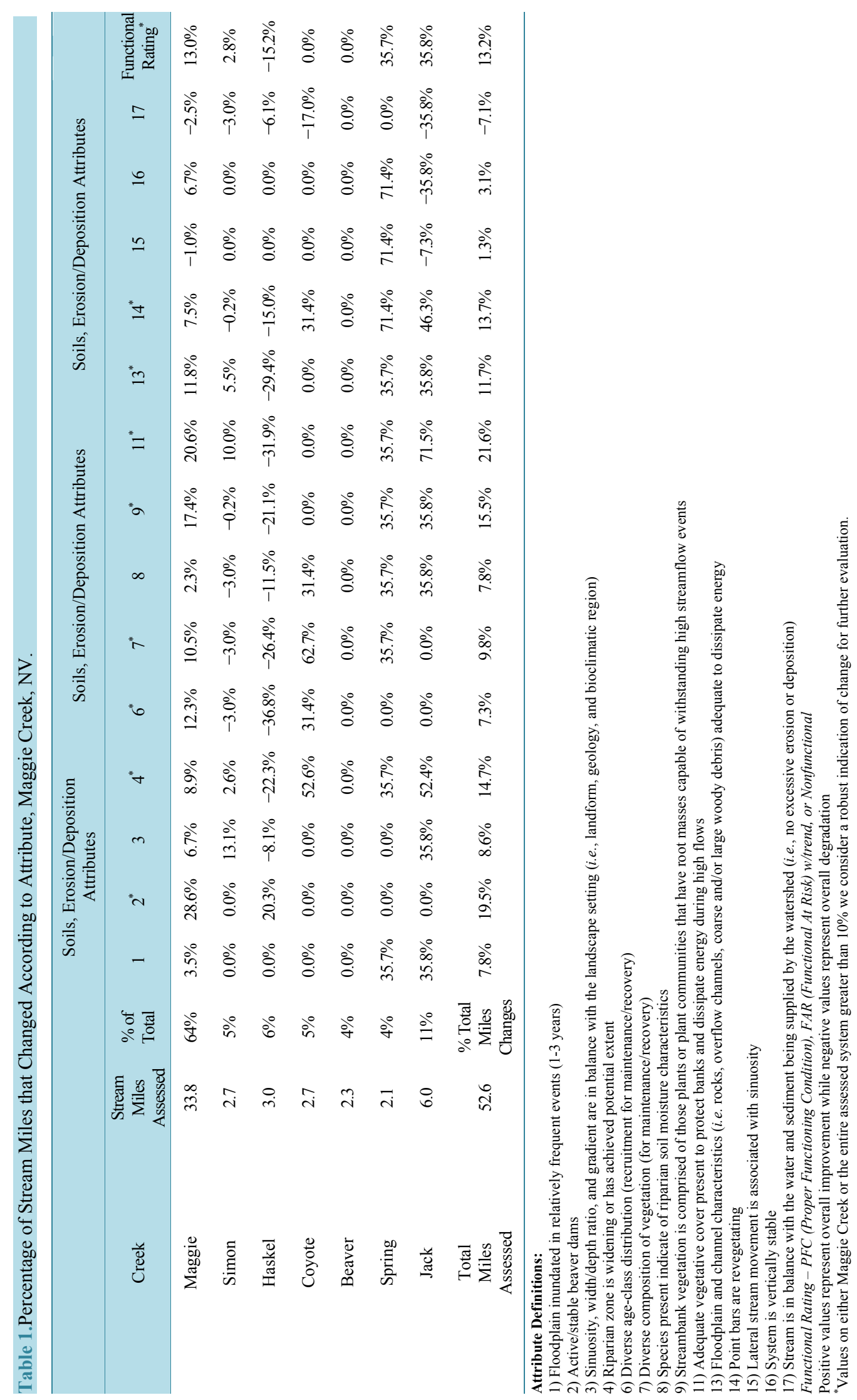




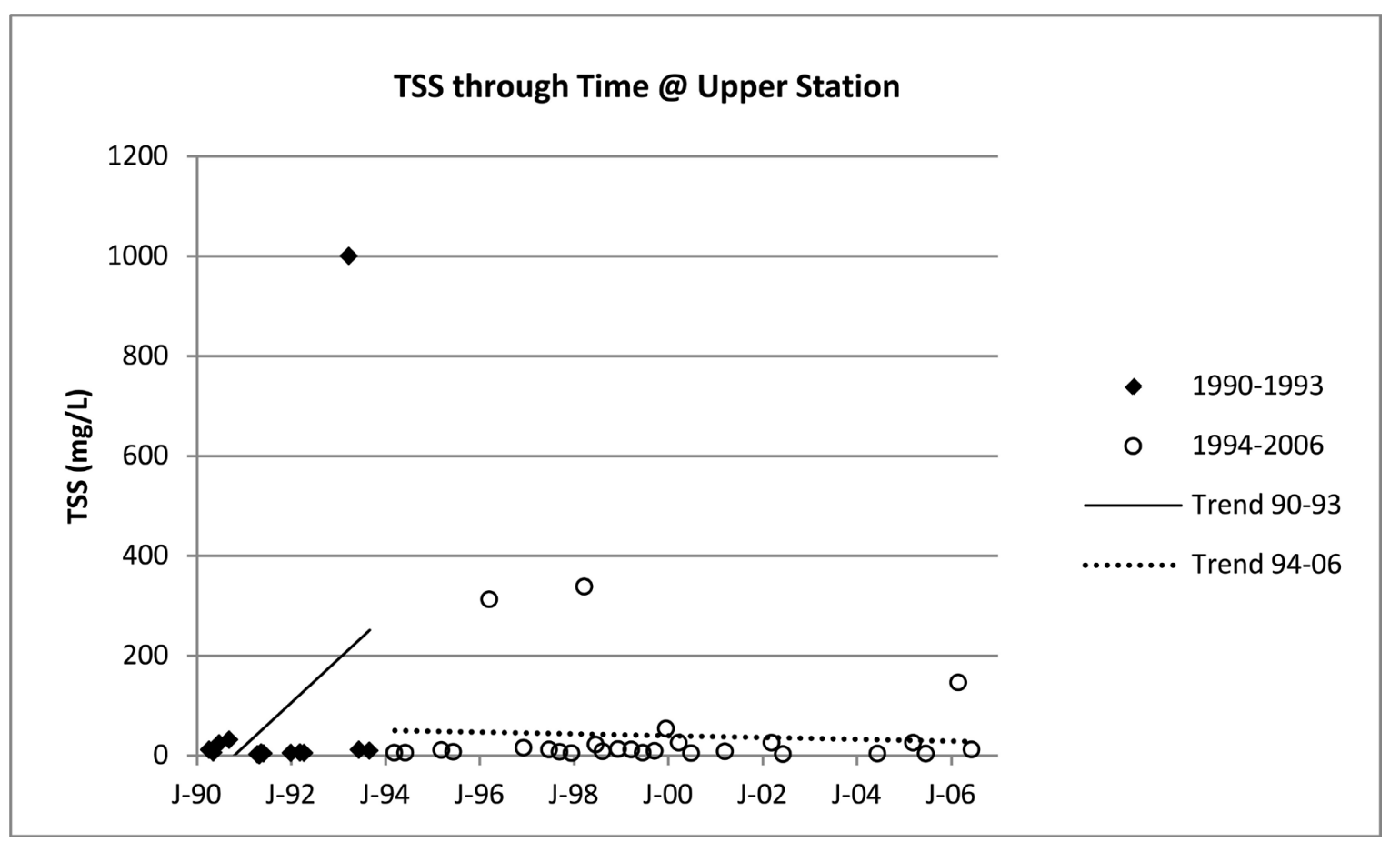

Figure 5. TSS trend at upper station, Maggie Creek, NV, pre- and post-management change.

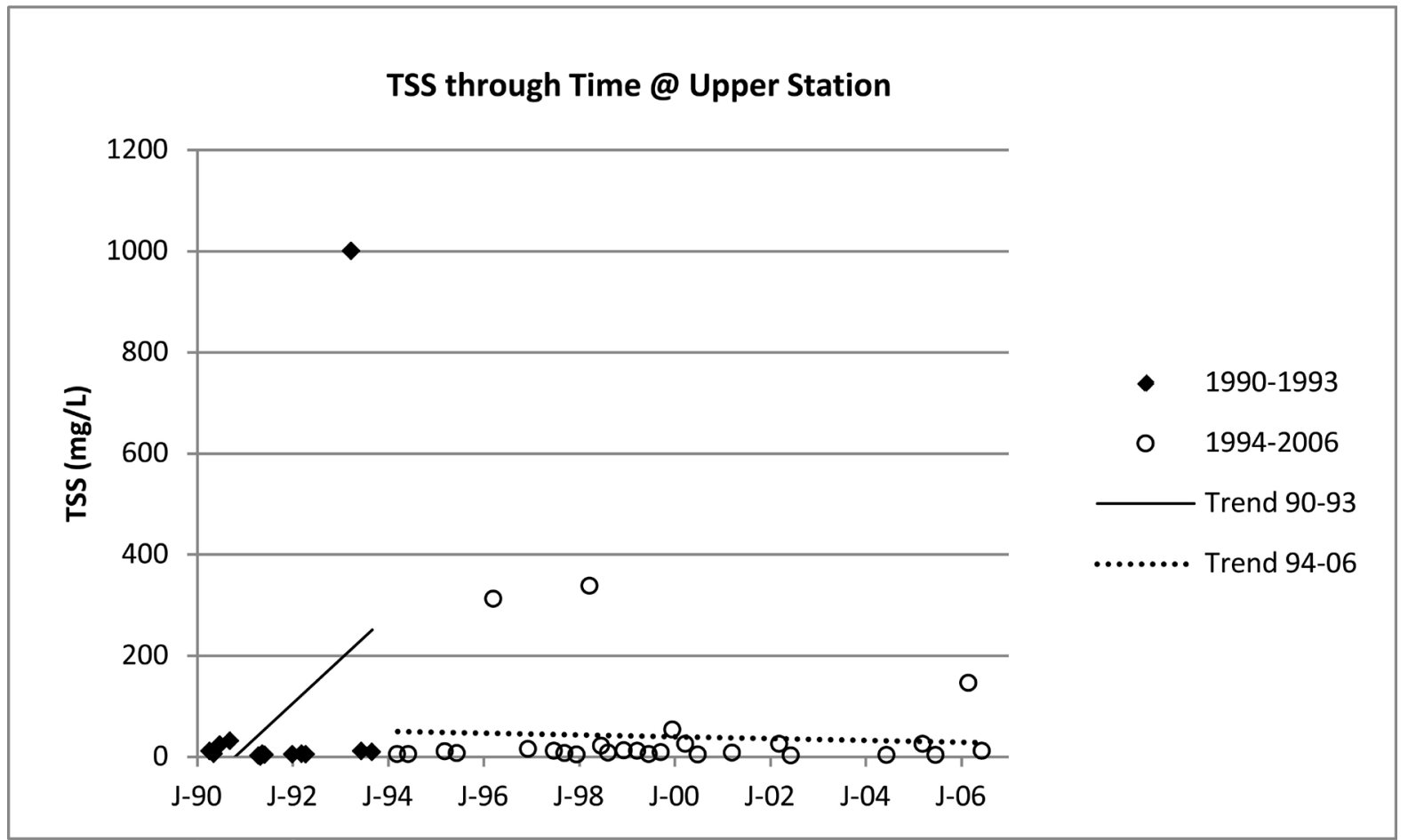

Figure 6. Sediment rating curves at upper station, Maggie Creek, NV.

Figure 6 displays the suspended solids rating curves at the upper station established for the beginning and ending periods of this study. A downward shift of the TSS rating curves indicates TSS became less concentrated at higher flows after a change in management. This could indicate an increase of in-stream channel shear stress resistance from an increase of hydrophilic riparian vegetation. Thus decreasing erosion and allowing for more 
suspended material to drop out of suspension and be deposited. At a discharge of $200 \mathrm{cfs}$, there was a modeled $46 \%$ reduction in TSS concentrations between before and after. While flows greater than $200 \mathrm{cfs}$ did occur during the later period, no TSS data where obtained during those times. Data for flows at or below bankfull suggests no significant TSS or temporal difference in TSS.

Sediment rating curve at the lower station (Figure 7) demonstrates the same downward shift as the upper station (Figure 6). Again, a comparison of TSS concentrations at a flow of $200 \mathrm{cfs}$ shows (Figure 8) a reduction of about $47 \%$ over the time periods. Note, what appears to be a threshold response around $125 \mathrm{cfs}$ in the 1993-1999 point data, where small increases in discharge seem to bring about large increases in TSS concentrations. This may be a signature of the release of reservoir water into lower Maggie Creek, or of incision and discharge large enough to contact gully banks above hydrophilic riparian vegetation. Below $50 \mathrm{cfs}$ (approximately $90 \%$ of all flows), there is little to no relationship between TSS and stream flow (Q).

The rating curves developed in Figure 6 and Figure 7 used the limited data available to this study. Figure 8 depicts rating curves established using a substantially larger data set collected by Newmont. The figure illustrates the need for large data sets to make simple, more accurate yearly comparisons. Note, the 2005 curve is highly influenced by only a couple of data points representing higher flows.

\subsection{Nitrogen: Total, Total Kjeldahl, and Nitrate + Nitrate}

Prior to 1994, the trend of both Total Nitrogen (TN) and Nitrogen Oxides (NOx) was sharply increasing at the lower station $\left(\mathrm{R}^{2}=0.31\right.$ and 0.28 , respectively) (Figure 9), representing a drought period that preceded a wet 1993. Total Kjeldahl $(\mathrm{TKN})$ increased $\left(\mathrm{R}^{2}=0.01\right)$ at a slower rate. After grazing management changes in 1994 , all nitrogen levels continued to increase, but all at moderate to slower rates. During the post-management change, NOx was a much smaller component of TN than before. Through time TKN contributed less, but still made up the majority of TN throughout the entire post-management change period. The average value of NOx-N prior to man-

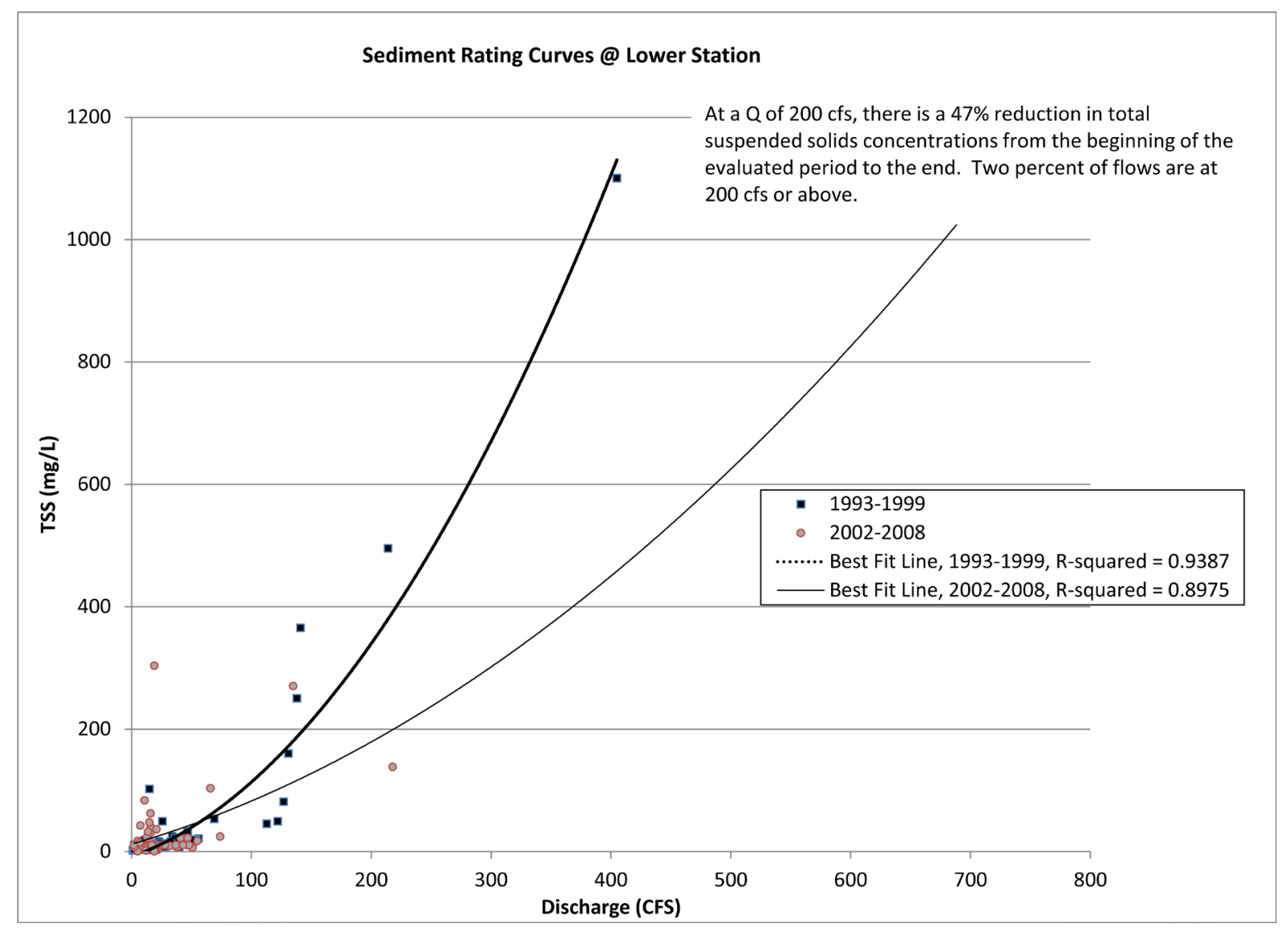

Figure 7. Sediment rating curves at lower station, Maggie Creek, NV. 


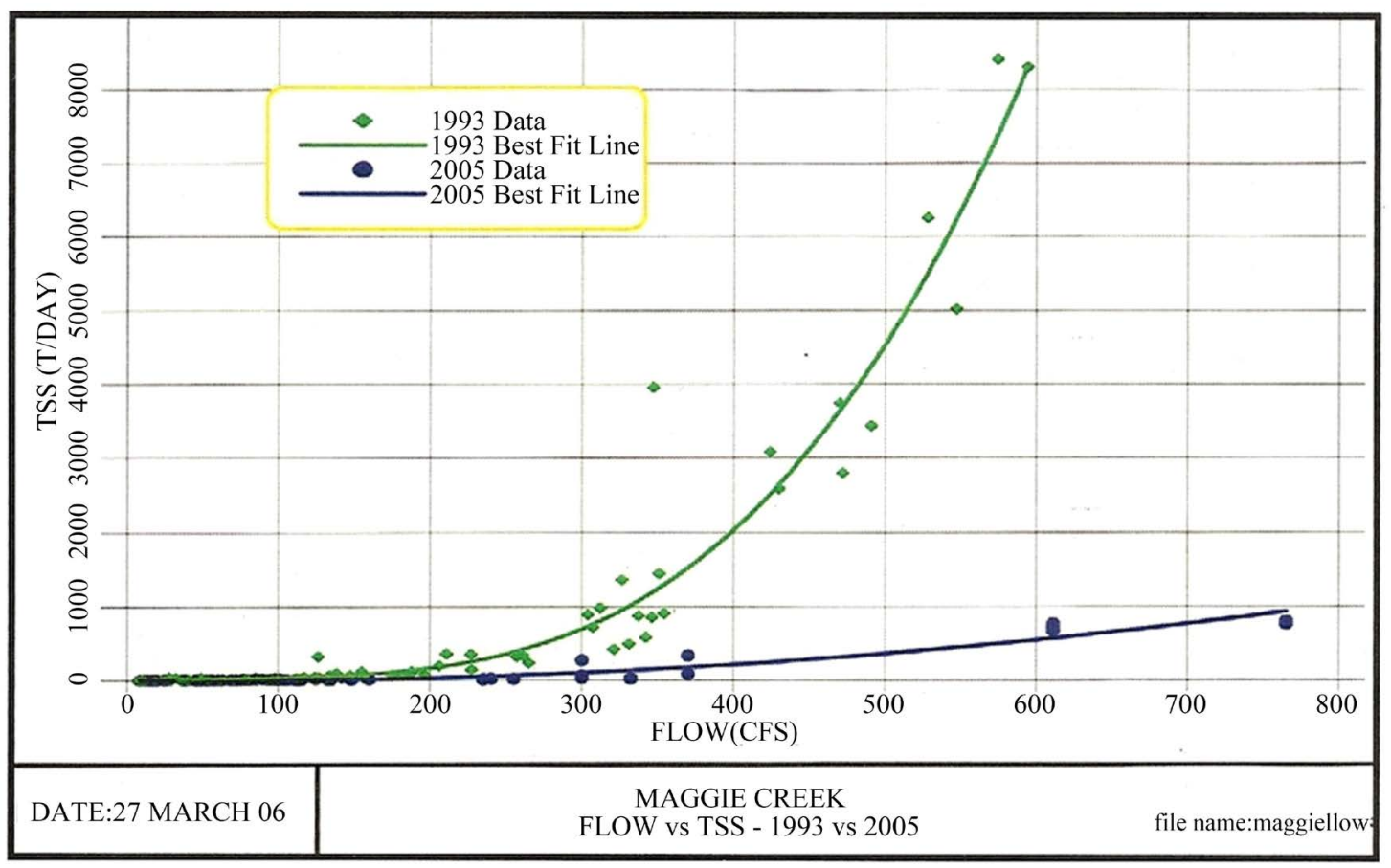

Figure 8. Rating curves developed by Newmont to illustrate TSS reductions through time (from Simonds et al. 2009), Maggie Creek, NV.

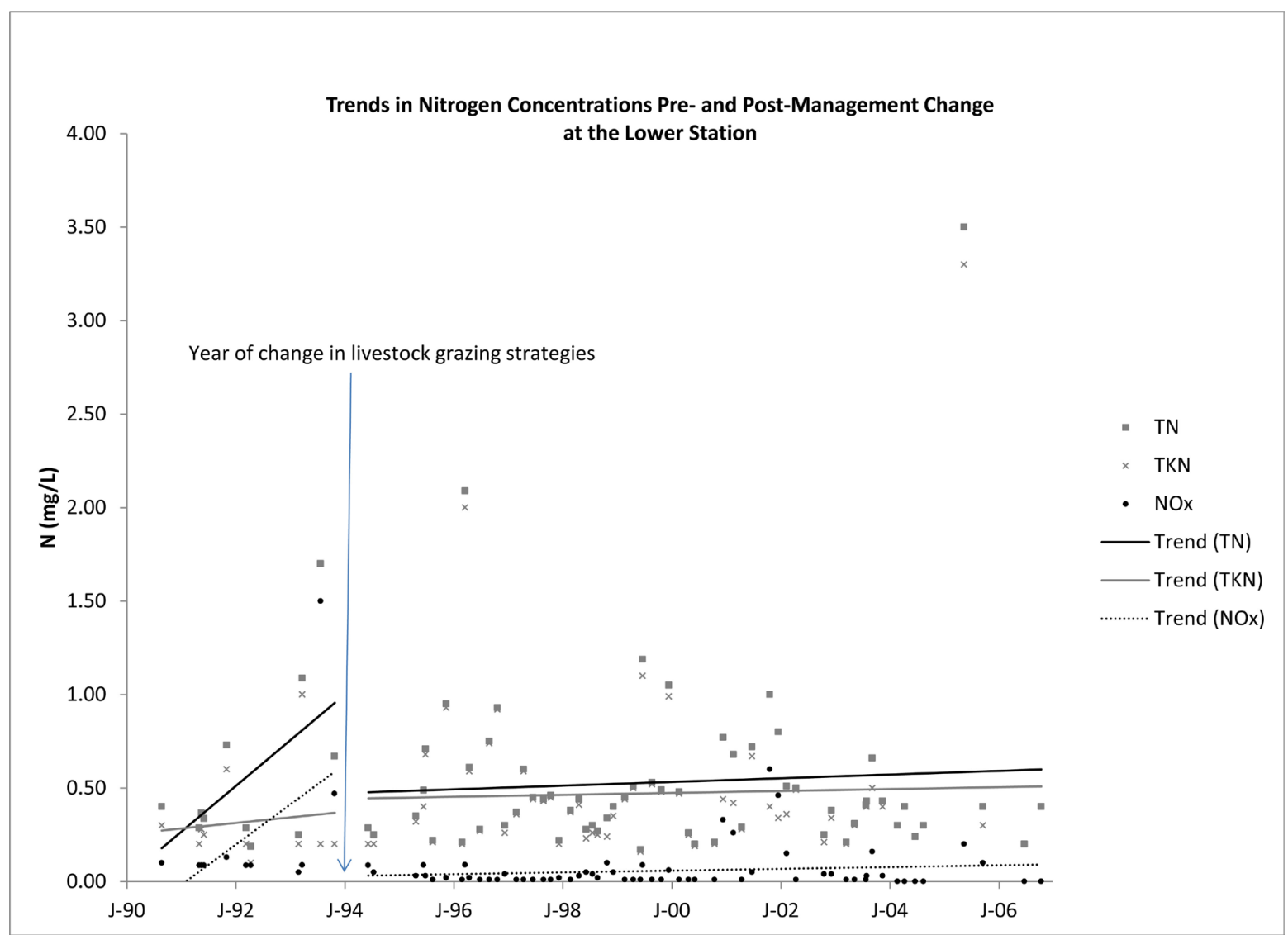

Figure 9. Nitrogen concentration trends at lower station, Maggie Creek, NV. 
agement change (1990-1993) was $0.25 \mathrm{mg} / \mathrm{L}$, nearly 6.5 times the average between the years $2003-2006(\mathrm{p}=$ 0.067).

Nitrogen data for the upper station are limited, consisting primarily of TKN data from 1991 through $1997(\mathrm{n}=$ 8 , all $\mathrm{R}^{2}<0.11$ ). Figure 10, shows these data compared to the lower stations for the same period and shows the upper station had slightly lower TKN concentrations compared to the lower station prior to management change $(p=0.02)$, but had higher concentrations post-change $(p=0.19)$. Figure 10 also demonstrates the continued increasing trend in concentrations as seen at the lower station.

\subsection{Dissolved Oxygen}

The Dissolved Oxygen (DO) concentration over time at the upper station increased during both pre- and postmanagement change. At the upper station post management increase in DO was at a much slower rate. The concentration of DO over time at the lower station had an increasing trend pre-management change $\left(\mathrm{R}^{2}=0.32\right)$ and a slightly declining trend post management $\left(\mathrm{R}^{2}=0.00\right)$. However, the increase in the pre-management change period at both stations was primarily caused by low water levels in the dry summer of 1991 .

\subsection{Orthophosphate Phosphorus}

Dissolved Orthophosphate Phosphorus (OP-P) values for all stations ranged from 0 to $1.6 \mathrm{mg} / \mathrm{L}$ with an average value of $0.13 \mathrm{mg} / \mathrm{L}$. The median value was $0.1 \mathrm{mg} / \mathrm{L}$ and the mode was $0 \mathrm{mg} / \mathrm{L}$. The recommended maximum level for rivers and streams is $0.1 \mathrm{mg} / \mathrm{L}$ [30]. Prior to management change, the trend in OP-P concentration was influenced by the March, 1993 runoff event. After the change in grazing management, OP-P tended to decrease $\left(\mathrm{R}^{2}=0.30\right)$. No data were available at the upper station beyond 1999 .

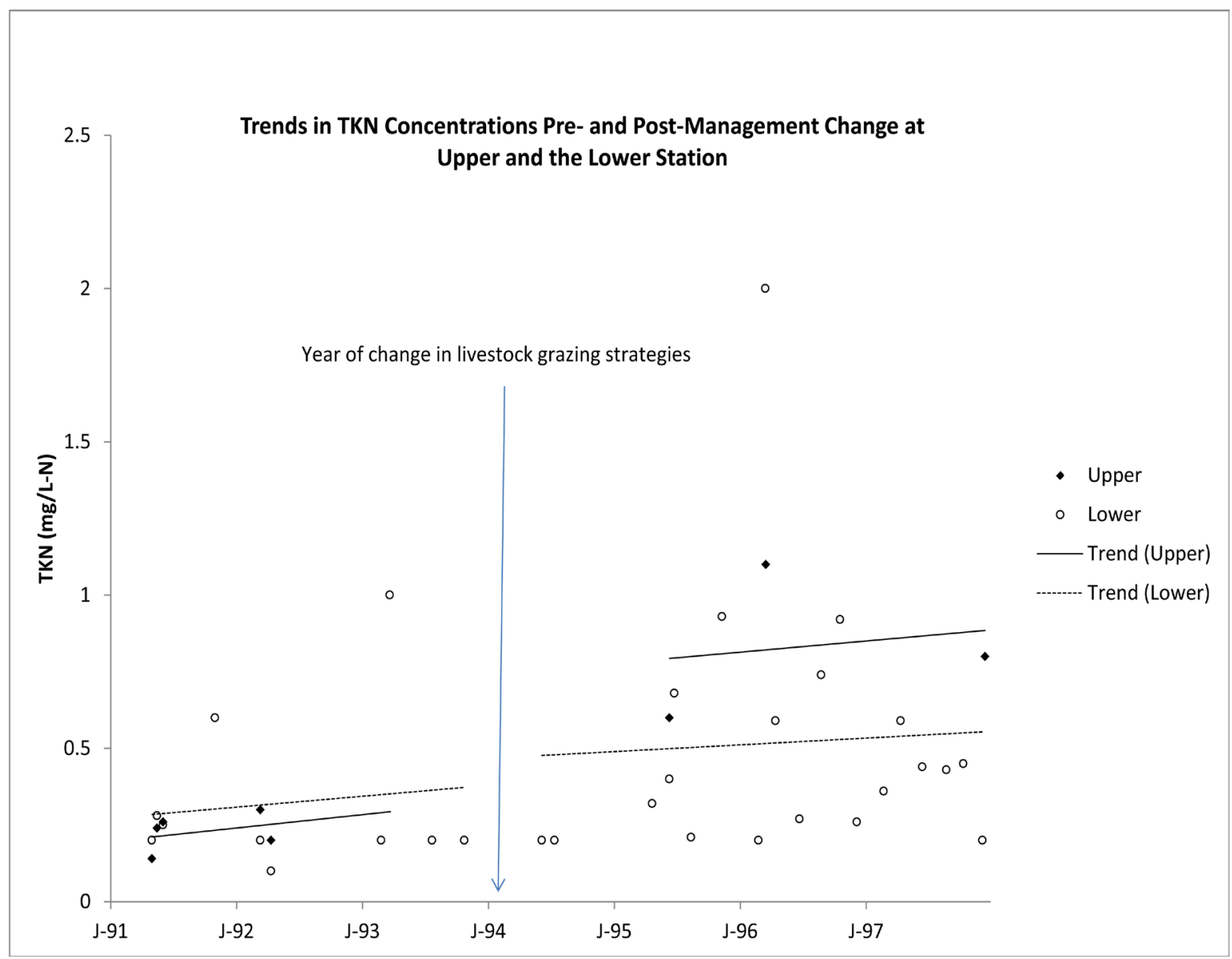

Figure 10. TKN concentration trends at the upper and lower stations, Maggie Creek, NV. 


\section{Discussion}

Beginning in 1994, a grazing management plan was developed using PFC assessment and implemented for portions (Figure 4) of the perennial/intermittent streams and the Twenty-Five ranch allotments in the Maggie Creek Watershed [27]. This greatly reduced the frequency and duration of hot season grazing on Maggie Creek and its tributaries. The area is divided into three zones including exclusion zones, a restoration zone, and a controlled grazing zone. The exclusion zone is closed to grazing while livestock use of the restoration zone is contingent on meeting and maintaining biological standards. The controlled grazing zone provides for rotational and deferred grazing practices. The extent of restoration accomplished by focused riparian grazing management is illustrated in Figure 11(a) and Figure 11(b). Both the exclusion and restoration zones support Lahontan Cutthroat Trout (Oncorhynchus clarkia ssp. Henshawi) LCT habitat. Other measures, including construction of water developments, tree plantings, prescribed burning, and development of a conservation easement were also part of the restoration effort.

The primary focus of the plan was to improve LCT habitat. Other efforts to improve fish populations included replacing culverts and irrigation diversions that bar migration, and placement of barriers at the bottom of the watershed to keep out non-native fish species. Trout Unlimited and partners are working within the watershed to monitor fish population response due to habitat improvement and barrier removal.

Land uses that most significantly affect water quality and aquatic habitat issues elsewhere in the Humboldt basin include grazing, irrigation agriculture, and mining. Changing grazing management and agricultural uses lead to changes in riparian functionality, which affects water quality and aquatic habitat variables. Open pit mining is prevalent in this watershed, but aerial images revealed no evidence that tailings or sediment from erosion was making its way into any of the studied stream reaches.

Impacts to PFC are far more prevalent from grazing, agricultural use, and roads than from mining in the Humboldt Basin, including Maggie Creek. Water quality variables that most closely respond to changes in land use/management in the Humboldt Basin include sediment (turbidity, total suspended solids), flow alteration (quantity, timing), nutrients, temperature, dissolved oxygen, pathogens and trace metals. Important aquatic habitat variables include riffle/pool ratios, bankfull width/depth ratios, embeddedness, and bank stability.

While each functional driver (vegetation, water, and soil/landform) is intertwined with the others (a functionality triangle or the "three-legged stool concept"), functional riparian vegetation is crucial for repair and maintenance. The vegetation responses due to the change in grazing strategy on Maggie Creek during the time of this study were addressed by [28]. Some of their key findings include:

- Substantial recovery of riparian vegetation as a consequence of changes in livestock management.

- $138 \%$ increase in riparian vegetation acreage within all prescribed grazing pastures, 1994 vs. 2006 via (CIR) analysis.

- $114 \%$ increase in riparian vegetation acreage of Maggie Creek Watershed Restoration Project (MCWRP) reaches, 1994 vs. 2006 (CIR).

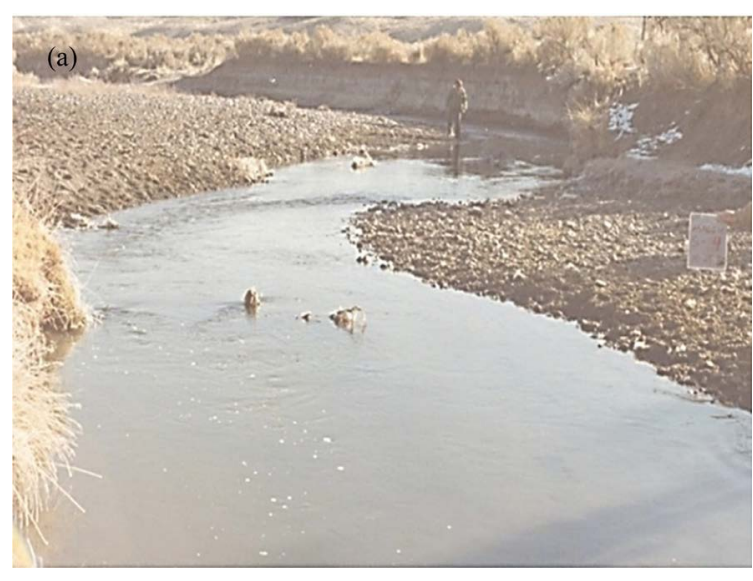

(a)

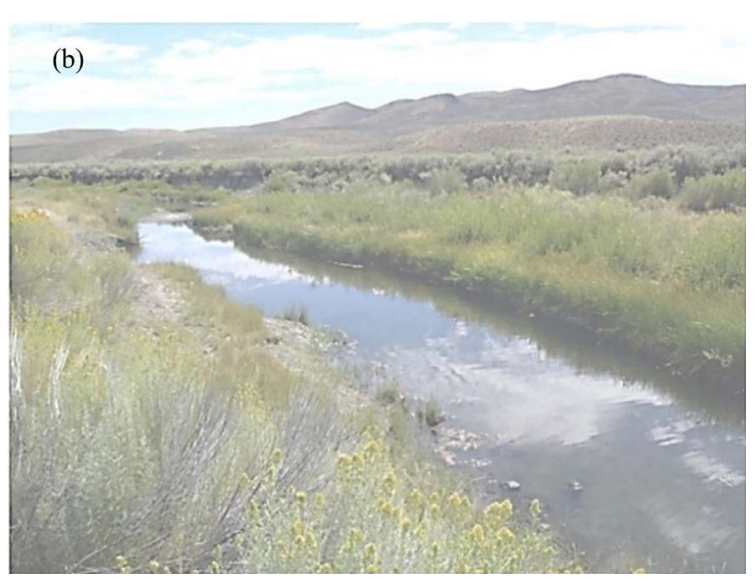

(b)

Figure 11. (a) Maggie Creek with season-long cattle grazing in November, 1980. (b), Maggie Creek in 2011 with shortened season of use differing among years since 1994. 
- Riparian recovery leading to elevated and more stable water tables.

- Well data in relation to precipitation, elevation, stream order, grazing use, and changes in riparian vegetation data suggest increased well elevations are correlated with increased vegetation beyond ambient influences.

- Percent of riparian vegetation in relation to the potential riparian area on Beaver Creek riparian pasture increased from 34\% in 2001 to $85 \%$ in 2006 (Landsat analysis).

Other geomorphic features related to PFC and aquatic habitats have been measured/evaluated by [28] and [29] including:

- $54 \%$ decrease in water acreage of MCWRP reaches, 1994 vs. 2006, CIR analysis (indication of narrowing channels, especially in light of the following).

- 7\% increase in stream length of MCWRP reaches, 1994 vs. 2006, CIR analysis (indication of increased sinuosity, which aids in energy dissipation and increased water storage capacity).

- $54 \%$ decrease in gravel acreage of MCWRP reaches, 1994 vs. 2006 , CIR analysis.

- Stream width to depth ratios decreased in all important LCT reaches monitored (1994 or 1996 to 2006).

- Woody riparian vegetation overhang generally tends toward increasing over time, but 2006 shows a decline likely due to the smothering by gravels from the 2006 flooding.

- Average number of quality pools has increased, with data starting from 1996. Quality pools are deeper and have more fish hiding cover.

- Limited hydrophytic plant cover data collected in 2006 by BLM and photos appear to support a wetter system than before.

- Streams generally show an improvement in PFC with the exception of the Lower Simon Creek Parcel (grazing practices questioned) and areas impacted by 2006 flooding.

- While 2006 flooding may have reduced the functionality ratings, riparian characteristics were effective at dissipating energy and capturing sediment, indicating that the riparian zone was functioning to maintain functions during a high flow event.

- Comparisons to survey data prior to 1994 indicate that riparian conditions have increased dramatically, with a substantial increase in riparian condition class, decrease in width to depth ratios, and increase in percent pool quality.

- Beaver activity has increased substantially, creating high quality pool habitat, especially in Maggie Creek.

These findings are consistent with and expected by the PFC assessments of this study. Two hydrologic, four vegetation, and two soil PFC attributes were found to have improved in over $10 \%$ of stream miles assessed, contributing to an overall improvement in the functional ratings of the reaches (Table 1). These improvements lead to the general hypothesis that all water quality parameters examined would show an improving trend, especially at the upper station. The only attribute that declined over total stream miles (by less than 10\%) was attribute 17 (stream is in balance with the water and sediment being supplied by the watershed). This was due to the excessive gravel loads that were moved during the 2006 floods. These gravels suggest that all reaches in the watershed may be relevant to functionality, even if reaches isolated by downstream ephemeral reaches are not relevant to water quality at monitoring stations.

Sediment rating curves for both stations indicated similar reductions in sediment transport, while it was hypothesized the lower stations should have less reduction. [28] cite a 2005 Newmont report that used an independent data set to determine a 10-fold decrease in sediment loads on Maggie Creek between 1993 and 2005, although the specific location of data collection is unclear in the Newmont report. Other water quality issues are related to sediment (e.g., nutrients), and sediment is itself a chief pollutant of concern. There were no known upland land management changes which would have changed sediment delivery to the stream system. In fact, three fires occurred within the watershed during the period of this study. Bare, unstable banks persisted prior to the study. Many became vegetated with enough of the appropriate riparian plant communities to not only reduce sediment delivery from bank erosion, but to effectively filter fire induced sediment. This too is a strong case for managing toward proper functioning condition.

Reductions in nutrients ( $\mathrm{P}$ and $\mathrm{N}$ ) were predicted. The results for this hypothesis were somewhat mixed, which is not surprising given the complex dynamics of nutrient cycling. It is expected that as plant communities expanded, nutrients would be taken up to meet growth needs and be filtered/processed by the expanded riparian width. It is also anticipated that litter material would become a source of nutrients eventually. However, it is thought the pace of uptake will be high enough to offset decomposition during this period of increasing riparian biomass and complexity. 
Phosphorus, being highly associated with sediment, was expected to decline. This was the case for OP-P Phosphorus release is expected during reducing conditions, which the majority of this system was clearly not experiencing during this time. Increased water oxygen levels coupled with increasing nitrate levels (addressed below) supports the assumption that Maggie Creek system was not dominated by a reducing environment. As the riparian systems continue to expand, a more reducing environment may eventually dominate. However, such an environment engages more effective sediment deposition on floodplains and more plant growth with nutrient uptake.

Phosphorus appeared to be effectively trapped and taken up by the riparian community during the time of this study. Total phosphorus is a nutrient of concern on Maggie Creek, being listed on the 2006 303(d) list as having a low TMDL priority. Continued decline in phosphorus could lead to delisting due to improved riparian functionality.

Nitrogen data are limited at the upper station, with only a few TKN values over a short time span to compare to the lower station. These data demonstrate comparably lower TKN concentrations prior to management change with indication of increasing trends. Post-management change saw continued increasing trends, but a considerable increase in concentration at the upper station. This is likely the result of increased organic litter accumulation due to increased riparian plant communities just upstream from the upper station.

The lower station had more nitrogen data than the upper station. NOx may accumulate during drought and then be flushed in high water flows, especially if flows come from uplands and precede the growing season. TKN is relatively low and barely exhibits an increasing trend. This indicates possible nitrogen sources other than vegetation. After management change, trend of all nitrogen forms leveled to slightly increasing, with the bulk of TN made up of TKN at the beginning. As the trend continues, TKN still makes the majority of TN, but progressively gives way to greater concentrations of NOx. This suggests that plant matter became the primary source of nitrogen in the system, and accumulating organic nitrogen from leaf litter was gradually starting to convert to nitrate/nitrite especially in more oxygenated conditions upstream. If functionality increases and anoxic conditions prevail, nitrogen will be sequestered in the riparian zone. A fluctuating high water table with available organic material (e.g., from roots) facilitates denitrification.

\section{Conclusions}

Rather than implement a sampling design tailored to address the specific hypotheses (realized to be an excessively expensive approach), this retrospective study was based on currently available data, which limited the ability to sufficiently address hypothesis questions. Even though water quality data for Maggie Creek watershed were dense in comparison to other watersheds for which the study questions could be asked, they were inadequate. The sediment rating curves suggested a difference between before and after the change in management, but the change in functionality allowed analysis based on only four points. One point was near the origin of the graph and represented base flow conditions. The other three points represented higher flows that were great enough to transport sediment (two before and one after). Because the Nevada Division of Environmental Protection protocol states that data from floods and droughts should not be used to evaluate whether water quality standards are being met, these special conditions are deemed inappropriate for basing impairment decisions. Therefore, one is left to use average flow data even though these conditions may not be critical for the beneficial use. It is during drought and seasonal low flows when fish populations generally suffer.

Interestingly, during dry periods riparian vegetation can help a stream recover by growing toward the remaining water. Subsequently, in wetter periods, vegetation is available to resist bank erosion, capture sediment, build banks and narrow the channel width. Furthermore, once the vegetation, especially woody plants thrive with grazing management, beaver dams can greatly increase aquifer water storage and base flows during dry periods [30]. Much stream habitat rebuilding occurs during floods if a stream has floodplain available for energy dissipation and vegetation in place for stabilizing banks and providing resistance to scouring flows.

In the Maggie Creek Watershed, the stream flows through three or four sequences of channel incision and recovery through gully widening. This is probably the major source of sediment (and nutrients or pollutants) in a watershed without upland watershed conditions that lead to riparian degradation. Thus, TSS data do not provide useful information to address the very reasons why monitoring data are collected and used to manage water quality. Furthermore, these data are so expensive (\$300 - 500 for lab fees plus labor and travel expenses to collect the sample per sampling event at one location), that they can be collected only at infrequent locations that represent large watersheds. This watershed contained almost one hundred reaches that were presumed to be re- 
levant to these water quality data and hundreds more where water quality and aquatic habitats are important to organisms and people. LCT lived in some of the tributary streams that were not addressed by this study because the intervening reaches were ephemeral. Yet this large watershed had water quality data from only two locations and only quarterly.

A far better approach to monitoring for water quality management is to monitor the drivers (leading indicators) rather than the lagging response indicators of water quality [31] [32]. The driving functions provide insight to the variables that should be the focus for monitoring and management. For water quality in rangeland or most other wild land aquatic habitats, riparian PFC focuses attention on those attributes useful for quantitative monitoring. An example of using these functions for focused monitoring is packaged in the Multiple Indicator Monitoring protocol [33]. This was developed to quantitatively monitor fish habitat and focused most attention on the conditions of riparian vegetation as it related to bank stability. To apply Multiple Indicator Monitoring or any other quantitative monitoring method, it is the most important to identify functional-at-risk downward trending reaches where a management change is needed or where a change has recently been implemented. The PFC items discussed above provide insight to needed attribute changes and help set good objectives. Good objectives should be specific, measureable, achievable, related to management and riparian functions, and valued by stakeholders. Since riparian conditions often depend on vegetation and the riparian management that drives changes in vegetation, riparian and water quality concerns should often focus on measuring vegetation change [34] [33]. Such objectives should change through time depending on the time scale of the management and monitoring plan. Early changes in vegetation show occupation of moist areas near a stream by colonizing vegetation. Later, the proportion of stabilizing wetland species increases and becomes capable of stabilizing streambanks. Because of the vegetation, the greenline to greenline width also narrows. All these drive improvement in fish habitat and water quality.

Water quality and aquatic habitat, particularly in rural areas, can be improved by returning riparian/wetland systems to a functional condition. Once in a functional condition, riparian areas can act as pollutant processors helping to mitigate water quality before it enters the waterway. Only by including the functionality of the riparian system can the TMDL process effectively address water quality issues.

\section{Acknowledgements}

The authors would like to thank Newmont Mining Company, and Carol Evans, Bureau of Land management, Elko District Office. We also like to thank Keith Enders for the critical review of this manuscript. The United States Environmental Protection Agency through its Office of Research and Development funded and managed the research described here under Student Services Contract number EP09D000249 to Donald F. Kozlowski while a student at the University of Nevada, Reno. The United States Environmental Protection Agency through its Office of Research and Development (funded and managed or partially funded and collaborated in) the research described here under (contract or assistance agreement number) to (name). It has been subjected to Agency review and approved for publication.

\section{References}

[1] Nakano, S., Miyasaka, H. and Kuhara, N. (1999) Terrestrial-Aquatic Linkages: Riparian Arthropod Inputs after Trophic Cascades in a Stream Food Web. Journal of Ecology, 80, 2435-2441.

[2] Hall, R.K., Guiliano, D., Swanson, S.R., Philbin, M.J., Lin, J., Aron, J.L., Schafer, R.J. and Heggem, D.T. (2014) An Ecological Function and Services Approach to Total Maximum Daily Load (TMDL) Prioritization. Journal of Environmental Monitoring, 186, 2413-2433. http://dx.doi.org/10.1007/s10661-013-3548-x

[3] BLM (Bureau of Land Management) (2001) Public Land Statistics 2000. Volume 185, BLM/BC/ST-01/001+1165, Accessed April, 2011.

[4] USEPA (2009) National Water Quality Inventory: Report to Congress 2004 Reporting Cycle. Office of Water, Washington, DC 20460, EPA 841-R-08-001. http://water.epa.gov/lawsregs/guidance/cwa/305b/upload/2009 01222 305b_2004report_2004_305Breport.pdf

[5] Prichard, D., Anderson, J., Correll, C., Fogg, J., Gebhardt, K., Krapf, R., Leonard, S., Mitchell, B., and Staats, J. (1998) Riparian Area Management: A User Guide to Assessing Proper Functioning Condition and Supporting Science for Lotic Areas. USDI BLM, USDA FS and NRCS Technical Reference 1737-15, $126 \mathrm{p}$.

[6] Dickard, M., Gonzales, M., Elmore, W., Leonard, S., Smith, D., Smith, S., Staats, J., Summers, P., Weixelman, D. and 
Wyman, S. (2015) Riparian Area Management-Proper Functioning Condition Assessment for Lotic Areas. BLM Technical Reference 1737-15, v.2, 193 p.

[7] Leonard, S., Staidl, G., Fogg, J., Gebhardt, K., Hagenbuck, W. and Prichard, D. (1992) Procedures for Ecological Site Inventory-With Special Reference to Riparian-Wetland Sites. US Department of the Interior Bureau of Land Management, Technical Reference 1737-7.

[8] California Wetlands Monitoring Workgroup (CWMW) (2013) California Rapid Assessment Method (CRAM) for Wetlands, Version 6.1, p. 67.

[9] Prichard, D., Barrett, H., Cagney, J., Clark, R., Fogg, J., Gebhardt, K., Hansen, P.L., Mitchell, B. and Tippy, D. (1993, 1995) Riparian Area Management: Process for Assessing Proper Functioning Condition. USDI BLM, USDA FS and NRCS Technical Reference 1737-9, 52 p.

[10] Ward, A.D. and Trimble, S.W. (2004) Environmental Hydrology. 2nd Edition, CRC 122 Press LLC, 2000 N.W. Corporate Blvd., Boca Raton, 475 p.

[11] Miller, J.R., House, K., Germanoski, D., Tausch, R.J. and Chambers, J.C. (2004) Fluvial Geomorphic Responses to Holocene Climate Change. In: Chambers, J.C. and Miller, J.R., Eds., Great Basin Riparian Ecosystems: Ecology, Management, and Restoration, Island Press, Washington DC, 49-87.

[12] Jensen, S., Ryel, R. and Platts, W. (1989) Classification of Riverine/Rip arian Habitat and Assessment of Nonpoint Source Impacts, North Fork Humboldt River Nevada. Report to USDA Forest Service, Intermountain Research Station, White Horse Associates, Smithfield, UT, 165 p.

[13] Kozlowski, D.F. (2007) Pre-Fire Functional Condition and Post-Fire Channel Changes in Northern Nevada Streams: The 1999-2001 Fires. Thesis, University of Nevada, Reno, 180 p.

[14] Bryce, S.A., Woods, A.J., Morefield, J.D., Omernik, J.M., McKay, T.R., Bracklry, G.K., Hall, R.K., Higgins, D.K., McMorran, D.C., Vargas, K.E., Petersen, E.B., Zamudio, D.C. and Comstock, J.A. (2003) Ecoregions of Nevada (Color Poster with Map, Descriptive Text, Summary Tables, and Photographs): Reston, VA. US Geological Survey (Map Scale 1:1,350,000).

[15] BLM (Bureau of Land Management) (1993) Final Environmental Impact Statement, Newmont Gold Company’s South Operations Area Project. Internal Report, Including Appendix A, Mitigation Plan, Elko District, Elko, Nevada.

[16] Miller, R.F. and Rose, J.A. (1999) Fire History and Western Juniper Encroachment in Sagebrush Steppe. Journal of Range Management, 52, 550-559. http://dx.doi.org/10.2307/4003623

[17] Miller, R.F., Chambers, J.C., Pyke, D.A., Pierson, F.B. and Williams, C.J. (2013) A Review of Fire Effects on Vegetation and Soils in the Great Basin Region: Response and Ecological Site Characteristics. Gen. Tech. Rep. RMRS GTR-308, Fort Collins, CO: US Department of Agriculture, Forest Service, Rocky Mountain Research Station, 126 p.

[18] Strahler, A.N. (1964) Geology Part II. Quantitative Geomorphology of Drainage Basins and Channel Networks. Section 4-II. In: Chow, Y.T., ED., (Ed in Chief), Handbook of Applied Hydrology, McGraw-Hill, New York, 4-39 to 4-76.

[19] Rosgen, D. (1996) Applied River Morphology. Wildland Hydrology, Pagosa Springs.

[20] Rosgen, D. (2006) Watershed Assessment of River Stability and Sediment Supply (WARSSS). Wildland Hydrology, Fort Collins.

[21] Knighton, D. (1998) Fluvial Forms and Functions: A New Perspective. Arnold London Publications, London, 383 pgs.

[22] Dunne, T. and Leopold, L.B. (1978) Water in Environmental Planning. Freeman, New York, 818 p.

[23] Mann, C.C. (2005) 1491—New Revelations of the Americas before Columbus. Vintage Books of Random House, New York, $541 \mathrm{p}$.

[24] Manning, M.E. and Padgett, W.G. (1995) Riparian Community Type Classification for Humboldt and Toiyabe National Forests, Nevada, and Eastern California. USDA Forest Service, Intermountain Region, R4-Ecol-95-01, 306 p.

[25] Weixelman, D., Zamudio, D., and Zamudio, K. (1996) Central Nevada Riparian Field Guide. R4-ECOL-96-01, USDA Forest Service, Intermountain Region, $145 \mathrm{p}$.

[26] Clemmer, P. (1994) (Revised 2001). Riparian Area Management: The Use of Aerial Photography to Manage Riparian-Wetland Areas. USDI BLM Technical Reference 1737-10, $55 \mathrm{p}$.

[27] US Environmental Protection Agency (1986) Quality Criteria for Water: 1986. Washington DC, US Environmental Protection Agency Report 440/5-86-001, Office of Water, September 1986.

[28] Simonds, G., Ritchie, M. and Sant, E. (2009) Evaluating Riparian Condition and Trend in Three Large Watersheds. Open Range Consulting. http://www.openrangeconsulting.com/watershed/watershed report.pdf

[29] Evans, C. (2009) Maggie Creek Watershed Restoration Project 1993 South Operations Area Project Mitigation Plan: 2006 Monitoring Summary and Evaluation of Biological Standards. Elko District, Bureau of Land Management, Internal Report.

[30] Swanson, S.R., Wyman, S. and Evans, C. (2015) Practical Grazing Management to Maintain or Restore Riparian Func- 
tions and Values. Journal of Rangeland Applications, 2, 1-28.

[31] Swanson, S.R., Hall, R.K., Heggem, D.T., Lin, J., Kozlowski, D.F. and Gibson, R.J. (2012) Leading or Lagging Indicator for Water Quality Management. Abstracts with Programs. 8th National Monitoring Conference, Portland, 30 April-4 May 2012.

[32] Aron, J.L., Hall, R.K., Philbin, M.J. and Schafer, R.J. (2013) Using Watershed Function as the Leading Indicator for Water Quality. Water Policy. http://dx.doi.org/10.2166/wp.2013.111

[33] Burton, T., Smith, S. and Crowley, E. (2011) Multiple Indicator Monitoring (MIM) of Stream Channels and Streamside Vegetation. Bureau of Land Management, Technical Reference 1737-23, 155 p.

[34] Winward, A.H. (2000) Monitoring the Vegetation Resources in Riparian Areas. Gen. Tech. Rep. RMRS-GTR-47. US Department of Agriculture, Forest Service, Rocky Mountain Research Station, Fort Collins.

\section{Submit or recommend next manuscript to SCIRP and we will provide best service for you:}

Accepting pre-submission inquiries through Email, Facebook, Linkedin, Twitter, etc A wide selection of journals (inclusive of 9 subjects, more than 200 journals)

Providing a 24-hour high-quality service User-friendly online submission system

Fair and swift peer-review system

Efficient typesetting and proofreading procedure

Display of the result of downloads and visits, as well as the number of cited articles

Maximum dissemination of your research work

Submit your manuscript at: http://papersubmission.scirp.org/ 